\title{
Association between zinc pool sizes and iron stores in premenopausal women without anaemia
}

\author{
Katsuhiko Yokoi ${ }^{1 *}$, Harold H. Sandstead ${ }^{2}$, Norman G. Egger ${ }^{3}$, Nancy W. Alcock ${ }^{2}$, V. M. Sadagopa \\ Ramanujam $^{2}$, Hari H. Dayal ${ }^{2}$ and James G. Penland ${ }^{4}$ \\ ${ }^{1}$ Department of Human Nutrition, Seitoku University Graduate School, 550 Iwase, Matsudo, Chiba 271-8555, Japan \\ ${ }^{2}$ Department of Preventive Medicine and Community Health, The University of Texas Medical Branch, Galveston, TX, USA \\ ${ }^{3}$ Division of General Internal Medicine, Mayo Clinic, Rochester, MN, USA \\ ${ }^{4}$ United States Department of Agriculture Agricultural Research Service, Grand Forks Human Nutrition Research Center, \\ Grand Forks, ND, USA
}

(Received 3 January 2007 - Revised 17 May 2007 - Accepted 24 May 2007)

The simultaneous occurrence of $\mathrm{Zn}$ and Fe deficiencies in man has been known since the discovery of human $\mathrm{Zn}$ deficiency. However, it is not established that low Fe stores per se or Fe-deficiency anaemia infer low $\mathrm{Zn}$ status. Therefore our objective was to identify relationships between $\mathrm{Zn}$ and $\mathrm{Fe}$ status in premenopausal women without anaemia. We also examined the contribution of food frequencies and blood loss to $\mathrm{Zn}$ and $\mathrm{Fe}$ status. The subjects were thirty-three apparently healthy premenopausal women without anaemia, who were not taking dietary supplements containing $\mathrm{Zn}$ or Fe or oral contraceptives. Main outcomes were $\mathrm{Zn}$ kinetic parameters based on the three-compartment mammillary model and serum ferritin (SF) concentration; contributing factors were the frequency of consumption of specific foods and menorrhagia. Lower SF was significantly associated with smaller sizes of $\mathrm{Zn}$ pools. The breakpoint in the relationship between SF and the lesser peripheral $\mathrm{Zn}$ pool was found to be $21.0 \mu \mathrm{g}$ $\mathrm{SF} / \mathrm{S}$. SF also correlated positively with frequency of beef consumption and negatively with bleeding through menstrual pads (BTMP). Similar to $\mathrm{SF}$, the Zn pool sizes correlated positively with frequency of beef consumption, and negatively with BTMP. In summary, Zn pool sizes and Fe stores were highly correlated in premenopausal women. SF concentrations $<20 \mu \mathrm{g} / \mathrm{l}$ suggest an increased likelihood of low Zn status.

Exchangeable zinc pool: Serum ferritin: Premenopausal women

Co-occurrence of severe $\mathrm{Zn}$ deficiency and Fe-deficiency anaemia was first observed in Zn-deficient Iranian farmers ${ }^{1}$ and confirmed in Egyptian farmers ${ }^{2,3}$. Subsequently, it was noted that $\mathrm{Zn}$ and $\mathrm{Fe}$ nutriture are affected by many of the same dietary factors ${ }^{4-6}$. Most recently, the co-occurrence of $\mathrm{Zn}$ and Fe deficiencies was described from Thailand ${ }^{7}$, India ${ }^{8}$ and Sri Lanka ${ }^{9}$. The latter study, adolescents with ferritin $<30 \mu \mathrm{g} / \mathrm{l}$ had a statistically significant relative risk of 1.7 for serum $\mathrm{Zn}<9.95 \mu \mathrm{mol} / 1$.

Based on the above, we propose a commonality hypothesis that both indices of $\mathrm{Zn}$ nutriture (plasma $\mathrm{Zn}$ and $\mathrm{Zn}$ pool sizes) and Fe nutriture (serum Fe and serum ferritin) are correlated with frequencies of consumption of common foods containing bioavailable $\mathrm{Zn}$ and $\mathrm{Fe}$ or their absorption inhibitors and enhancers, and that both $\mathrm{Zn}$ indices and Fe indices are correlated in premenopausal women with normal $\mathrm{Fe}$ status or low Fe status without anaemia.

Circumstantial evidence favours the commonality hypothesis. $\mathrm{Zn}$ and $\mathrm{Fe}$ are most bioavailable from many of the same foods and their absorption is inhibited by many of the same dietary substances ${ }^{6}$. Consistent with this relationship, a preliminary study ${ }^{10}$ found accelerated $\mathrm{Zn}$ disappearance and increased $\mathrm{Zn}$ turnover rate in eighteen young women from Galveston, TX, USA with serum ferritin concentrations $<20 \mu \mathrm{g} / \mathrm{l}$, a criterion to detect low Fe stores ${ }^{11-13}$. More recently, inadequate dietary intakes of $\mathrm{Zn}$ and $\mathrm{Fe}$ that failed to meet the high physiological demands of adolescent girls in Australia and New Zealand were shown related to food choices $^{14}$. Relevant to these findings is the observation in fifty-two non-pregnant premenopausal women from Seattle, Washington, USA, whose diets provided similar amounts of $\mathrm{Fe}$, that consumption of red meat five times/week was more efficacious for body $\mathrm{Fe}$ stores than consumption of lactoovo-vegetarian foods, or the flesh of chicken and fish ${ }^{15}$. Mean serum ferritin concentrations associated with the three diets were $30 \cdot 5,19 \cdot 1$ and $15.6 \mu \mathrm{g} / \mathrm{l}$, respectively.

The Fe intake and red meat consumption of the British population has decreased during the past three decades according to the National Food Survey. Groups at particular risk of low Fe stores are females aged 11-64 years (18-21\%) with serum ferritin $<15 \mu \mathrm{g} / 1^{16}$. The continued high prevalence of Fe deficiency among premenopausal women in the USA is evident from findings of the United States National Health and Nutrition Examination Survey 2 (NHANES-II), which

Abbreviations: EZP, rapidly exchangeable Zn pool; FFM, fat-free mass; $Q_{1}$, central Zn pool; $Q_{2}$, lesser peripheral Zn pool; $Q_{3}$, greater peripheral Zn pool.

* Corresponding author: Dr Katsuhiko Yokoi, fax +81473631401, email KatsuhikoY@aol.com 
found a 25th percentile for serum ferritin of $14 \mu \mathrm{g} / \mathrm{l}$ in premenopausal women ${ }^{17}$, and NHANES-IV (1999-2000) which found a $19-22 \%$ prevalence of Fe deficiency (measured by 'two out of three' abnormal indicators: serum ferritin, transferrin saturation, and free erythrocyte protoporphyrin) in nonHispanic black and Mexican American women, a level about twice that in non-Hispanic white women ${ }^{18}$.

If, as suggested above, Fe and $\mathrm{Zn}$ nutriture are associated, then it is likely that Fe-deficient women in these surveys were also $\mathrm{Zn}$ deficient. While the worldwide prevalence of $\mathrm{Fe}$ deficiency with or without anaemia is uncertain, a conservative estimate is about $30 \%{ }^{19}$. Knowledge of the prevalence of $\mathrm{Zn}$ deficiency is more limited. A conservative estimate by the International Zinc Nutrition Consultative Group (IZiNCG), based on the food-balance sheets of the FAO and estimates of the average physiological requirements for absorbed $\mathrm{Zn}$, suggests that about $20 \%$ of the world's population is affected ${ }^{20}$.

The above findings suggest that Fe-deficient premenopausal women without anaemia are likely to be $\mathrm{Zn}$ deficient. To test this hypothesis we used stable-isotope technology to measure $\mathrm{Zn}$ kinetics ${ }^{6,21,22}$, and determined correlations between $\mathrm{Zn}$ nutriture (plasma $\mathrm{Zn}$ and $\mathrm{Zn}$ pool sizes) and $\mathrm{Fe}$ nutriture (serum $\mathrm{Fe}$ and serum ferritin), and of $\mathrm{Zn}$ and $\mathrm{Fe}$ indices with the frequencies of consumption of common foods.

\section{Subjects and methods}

Setting

The present study was accomplished in out-patient and inpatient settings. Initially respondents to advertisements were interviewed by telephone, then selected potential subjects were interviewed face to face in an office of the Division of Human Nutrition and laboratory specimens were collected using a treatment room in the Division of Human Nutrition, then the subjects were admitted to the General Clinical Research Center for about $48 \mathrm{~h}$ while $\mathrm{Zn}$ kinetics were measured. The Institutional Review Board of the University reviewed and approved the project. Each participant was informed verbally and using printed forms; each indicated her consent by signature, and each was given a copy of her signed consent form.

\section{Participants}

The participants were thirty-three apparently healthy premenopausal women, aged 19-39 years, from Galveston (TX, USA) and nearby communities. They were selected from 708 respondents of various ethnic backgrounds who responded to advertisements and were interviewed by telephone to exclude individuals with exclusion factors. This process identified 323 potential subjects who were screened in more detail. Inclusion criteria included: informed consent, a history consistent with good health, regular menses with a $24-34$ d cycle, completion of twelve grades of school, income $>2 \times$ poverty, and normal physical examination and laboratory screening tests. Exclusion criteria included: anaemia $(\mathrm{Hb}<110 \mathrm{~g} / \mathrm{l})$, chronic or recurrent illnesses, eating disorders, chronic medication, consumption of nutritional supplements that contained $\mathrm{Fe}$ and/or $\mathrm{Zn}$ within $60 \mathrm{~d}$, skipped menstrual periods in the preceding month, alcohol consumption $>2$ ounces $(57 \mathrm{~g})$ daily, smoking
$>$ ten cigarettes daily, and use of controlled substances. After informed consent, a structured interview obtained socio-demographic and medical history data, and a food frequency history. A physical examination was done, and specimens of blood and urine were collected for a laboratory evaluation by the Hospital Clinical Pathology Laboratory.

Blood analytes included: serum concentrations of ferritin as a measure of $\mathrm{Fe}$ stores ${ }^{23,24}, \mathrm{Fe}$, electrolytes $(\mathrm{Na}, \mathrm{Cl}, \mathrm{Ca}$, inorganic phosphate, bicarbonate and anion gap), liver enzymes, cholesterol, creatinine, and urea N. Haematological examination included $\mathrm{Hb}$ concentration, erythrocyte indices, leucocyte differential count and erythrocyte sedimentation rate. Urinalysis included specific gravity, protein, glucose, and microscopic examination of sediment.

Individuals ( $n$ 129) who met all selection criteria were enrolled in the randomised controlled trial of $\mathrm{Zn}$ treatment or Fe treatment in the context of adequate intakes of other micronutrients on neuropsychological performance. Results will be reported elsewhere; a preliminary evaluation suggested $\mathrm{Zn}$ was efficacious for several tasks and $\mathrm{Fe}$ was efficacious for one task ${ }^{25}$. The findings concerning $\mathrm{Zn}$ were consistent with previous observations on 740 Chinese children aged 6-9 years of age $\mathrm{e}^{26}$.

$\mathrm{Zn}$ kinetics were measured in the first fifty subjects after they had been administered the oral micronutrient supplement without $\mathrm{Zn}$ or $\mathrm{Fe}$ for at least $7 \mathrm{~d}$. The micronutrient supplement was given to replenish latent deficiencies that might suppress the efficacious effect of $\mathrm{Zn}^{26-28}$. The micronutrient supplement provided all micronutrients that in 1989 were designated an RDA or estimated safe and adequate daily dietary intake (ESADDI) by the Food and Nutrition Board, National Academy of Sciences, USA, in an amount that was $50 \%$ of the RDA or ESADDI for women this age. Based on the self-reported questionnaire, the thirty-three subjects who were not taking oral contraceptives were selected from the fifty subjects for the present report.

\section{Outcomes}

The main baseline outcomes relevant to the present report were food frequency, menstrual history, and indices of $\mathrm{Fe}$ and $\mathrm{Zn}$ status. Of the latter, $\mathrm{Zn}$ kinetics were measured on days $8-12$ of the menstrual cycle.

\section{Zinc tracer}

The procedures for $\mathrm{Zn}$ kinetics have been reported ${ }^{6,10,29}$. Subjects were admitted to the University of Texas Medical Branch General Clinical Research Center (Galveston, TX, USA). Meals provided $<6 \mathrm{mg} \mathrm{Zn} / 24 \mathrm{~h}$. On the first night, subjects were fasted for at least $8 \mathrm{~h}$. The next morning blood samples were collected, using trace metal-free syringes and tubes, for indices of $\mathrm{Fe}$ and $\mathrm{Zn}$ status, and the ${ }^{67} \mathrm{Zn}$ chloride tracer was administered as follows.

The ${ }^{67} \mathrm{Zn}$ chloride tracer was prepared from ${ }^{67} \mathrm{Zn}$ oxide $\left({ }^{67} \mathrm{Zn}\right.$ natural abundance $4.11 \%$; enrichment, $93.11 \%$; Oak Ridge National Laboratories, Oak Ridge, TN, USA). The ${ }^{67} \mathrm{Zn}$ chloride solution was tested for sterility (Department of Clinical Microbiology and Immunology, University of Texas Medical Branch) and pyrogenicity (Scientific Associates Inc., St Louis, MO, USA). Short Teflon catheters were 
placed in both antecubital veins. After a baseline blood sample was taken, $2 \mathrm{mg}{ }^{67} \mathrm{Zn}$ as the chloride dissolved in normal saline was administered over $3 \mathrm{~min}$ through the catheter in one arm. Samples of at least $10 \mathrm{ml}$ were taken from the other arm at 5, 15, 30, 40, 50, 60 and $90 \mathrm{~min}$, and at 2, 6, 12 and $24 \mathrm{~h}$ after the administration of the ${ }^{67} \mathrm{Zn}$. $\mathrm{Zn}$ pool sizes were determined from the data over the $24 \mathrm{~h}$ observation period after intravenous administration of ${ }^{67} \mathrm{Zn}$.

\section{Body composition measurement}

The following morning, after an overnight $12 \mathrm{~h}$ fast, fat-free mass (FFM) was measured, with the bladder empty, by bioelectrical impedance analysis using a BIA-101A analyser (RJL Systems, Clinton Twp., MI, USA) ${ }^{30}$. Height (nearest $\mathrm{cm}$ ) and weight (nearest $0.1 \mathrm{~kg}$ ) were measured. Subjects were positioned supine with their arms and legs abducted. Signal-introducing electrodes were applied to the dorsal surface of the proximal phalanx of the right middle finger and just proximal to the middle toes of the dorsal surface of the right foot. Detecting electrodes were applied to the dorsal surface of the right wrist between the prominences of radius and ulna and on the dorsal side of the right ankle between the malleoli. FFM (nearest $0.1 \mathrm{~kg}$ ) was calculated using the software (Weight Manager version 2.05a; RJL Systems) provided by the manufacturer.

\section{Chemical analyses}

The plasma samples were digested with $\mathrm{H}_{2} \mathrm{O}_{2}(30 \%)^{31}$ and dissolved in $1 \%$ nitric acid. Plasma $\mathrm{Zn}$ was measured by flame atomic absorption spectrophotometry ${ }^{31} .{ }^{67} \mathrm{Zn}^{6}{ }^{68} \mathrm{Zn}$ ratios in plasma were measured by inductively coupled plasma-mass spectrometer VG PlasmaQuad-1, upgraded to a PlasmaQuad-2 plus status (VG Instruments, Winsford, Cheshire, $\mathrm{UK})^{32}$. The $\mathrm{CV}$ of the isotope ratio measurement was 0.2 to $0.6 \%$. Each sample was analysed with ten replicate runs to obtain optimal precision.

\section{Zinc kinetics}

Zn kinetic parameters including $\mathrm{Zn}$ pool sizes (Fig. 1), i.e. central Zn pool $\left(Q_{1}\right)$, lesser peripheral $\mathrm{Zn}$ pool $\left(Q_{2}\right)$, greater peripheral $\mathrm{Zn}$ pool $\left(Q_{3}\right)$ and rapidly exchangeable $\mathrm{Zn}$ pool (EZP) as a sum of $Q_{1}, Q_{2}$ and $Q_{3}$, were calculated based on a closed mammillary model as reported ${ }^{6}$. Zn pools $Q_{1}, Q_{3}$ and EZP were divided by FFM to obtain $Q_{1} / \mathrm{FFM}, Q_{3} / \mathrm{FFM}$ and EZP/FFM, because Zn pools except for $Q_{2}$ were almost proportional to FFM. The lesser peripheral $\mathrm{Zn}$ pool $Q_{2}$ that

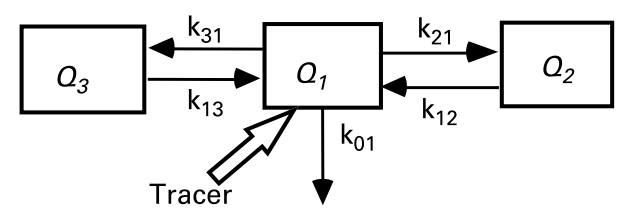

Fig. 1. Diagrammatic representation of the three-compartment mammillary model for human $\mathrm{Zn}$ kinetics. $Q_{3}$, size of the greater peripheral $\mathrm{Zn}$ pool (compartment 3); $Q_{2}$; size of the lesser peripheral $Z n$ pool (compartment 2); $Q_{1}$, size of the central $\mathrm{Zn}$ pool (compartment 1 ); $\mathrm{k}_{\mathrm{ij}}$, fractional transfer rate into compartment i from compartment $\mathrm{j} ; \rightarrow$, the point of $\mathrm{Zn}$ tracer administration. presumably represents a certain proportion of liver $\mathrm{Zn}$ did not correlate with $\mathrm{FFM}^{6}$. Therefore, $Q_{2}$ was not corrected by FFM.

\section{Food-frequency questionnaire}

Intake frequency of foods was assessed with a self-administered FFQ established by Willett et al. ${ }^{33}$. The study participants completed the questionnaire during their visits. The participants were instructed as follows: 'Please indicate how often you usually eat certain foods. Think about your usual diet over the past month. How often do you usually eat these foods per day, per week, or per month? If you never ate them tick the never box and if you do not know how much you ate tick the DK (do not know) box.' Participants reported therefore their average intake frequency only (not portion sizes) over the past month. To facilitate understanding by subjects, examples of dishes that contain the specified food item were shown.

\section{Statistical tests}

Simple and multiple regressions and non-linear regression with the broken-line equation ${ }^{6}$ were used to analyse the relationships between $\mathrm{Fe}$ and $\mathrm{Zn}$ indices and those between food frequencies and $\mathrm{Fe}$ and $\mathrm{Zn}$ indices. If non-linearity was observed by the inspection of plots, the data were fitted to the broken-line equation. In regression analyses, food frequencies (number of consumptions per week) were used as independent variables, as were biochemical and anthropometric parameters and the index of excessive menstrual blood loss. As an objective index of excessive menstrual blood loss, a history of 'bleeding through menstrual pads' was used ${ }^{10}$. If the subjects answered 'yes' to the question 'bleeding through menstrual pads', 1 was given to the bivalent variable. When the subjects answered 'no', 0 was given.

The variables included in the initial independent variable set for stepwise multiple regression analysis of $\mathrm{Zn}$ indices and $\mathrm{Fe}$ parameters were body height, $\mathrm{Hb}$, serum ferritin, serum $\mathrm{Fe}$ and bleeding through menstrual pads. For $Q_{2}$, FFM was also added to the initial set.

The variables included in the initial independent variable set for stepwise multiple regression analysis of the relationship between $\mathrm{Fe}$ and $\mathrm{Zn}$ indices (serum ferritin, serum $\mathrm{Fe}$, plasma $\mathrm{Zn}$, Zn pool sizes) and food frequencies were consumption (times/week) of beef, vitamin C-fortified drinks, orange juice, eggs, yoghurt, milk, coffee, tea, beans and bran breakfast cereals, and body height and bleeding through menstrual pads. FFM was also added to the initial variable set for the analysis of serum ferritin, serum Fe, plasma $\mathrm{Zn}$ and $Q_{2}$.

The independent variables were selected from the initial independent variable set by the backward variable selection with $P \leq 0.10$ as an inclusion criterion and $P>0.10$ as an exclusion criterion. Outliers were serially detected when the $P$ values for the Studentised residual were less than 0.05 with Bonferroni's correction in regression analyses. All statistical tests including simple linear regression, stepwise multiple linear regression, non-linear regression and Fisher's exact probability test were done using the SYSTAT software version 10.2 (Systat Software, Inc., San Jose, CA, USA). $P$ values $<0.05$ were considered significant. 


\section{Results}

\section{Characteristics of subjects}

The characteristics of the thirty-three subjects are shown in Table 1. Ethnicity designated by the subjects included twentyone non-Hispanic whites, four African-Americans, one Asian and seven with Spanish surnames. Since anaemia was an exclusion factor, $\mathrm{Hb}$ concentrations were $>110 \mathrm{~g} / \mathrm{l}$. Twenty-one subjects had serum ferritin concentration $<20 \mu \mathrm{g} / \mathrm{l}$, a criterion to detect low Fe stores ${ }^{11-13}$. Three subjects had Fe-deficient erythropoiesis (erythrocyte protoporphyrin $>1000 \mu \mathrm{g} / \mathrm{l}^{34}$. Consistently, a significant inverse relationship $(P<0.005)$ was found between serum ferritin and erythrocyte protoporphyrin (Fig. 2). When the data were limited within serum ferritin less than $20 \mu \mathrm{g} / \mathrm{l}$, no correlation was observed $(P=0 \cdot 897)$. Serum ferritin concentration of all subjects with Fe-deficient erythropoiesis was $<20 \mu \mathrm{g} / \mathrm{l}$. Seventeen subjects had plasma $\mathrm{Zn}$ concentration $<10.7 \mu \mathrm{mol} / \mathrm{l} \quad(700 \mu \mathrm{g} / \mathrm{l})$. Food frequencies (times/week) of the subjects are shown in Table 2. Five subjects out of thirty-three reported a history of bleeding through menstrual pads.

\section{Relationship between iron parameters and zinc pool sizes}

The correlation coefficients between $\mathrm{Zn}$ pool sizes and plasma $\mathrm{Zn}$ concentration, serum Fe concentration, and serum ferritin concentration are shown in Table 3. Plasma $\mathrm{Zn}$ positively and significantly correlated with $Q_{1} / \mathrm{FFM}$ and $Q_{2}$. Serum Fe positively and significantly correlated with plasma $\mathrm{Zn}$ and $Q_{2}$. Serum ferritin positively and significantly correlated with plasma $\mathrm{Zn}, Q_{1} / \mathrm{FFM}, Q_{2}, Q_{3} / \mathrm{FFM}$ and EZP/FFM.

The relationship between Fe parameters and $\mathrm{Zn}$ pool sizes was further analysed by stepwise regression analysis as shown in Table 4. Simple and multiple regression analysis found serum ferritin positively correlated with $Q_{1} / \mathrm{FFM}$. The effect of excessive menstrual bleeding exemplified by bleeding through menstrual pads on $Q_{1} / \mathrm{FFM}$ was marginal $(0.05<P<0 \cdot 10)$. Simple and multiple regression analysis also found serum ferritin and serum $\mathrm{Fe}$ as positively correlated with $Q_{2}$. Simple and multiple regression analysis found serum ferritin to be positively correlated with $Q_{3} / \mathrm{FFM}$. Similar to $Q_{3} /$ FFM, both simple and multiple regression analysis found

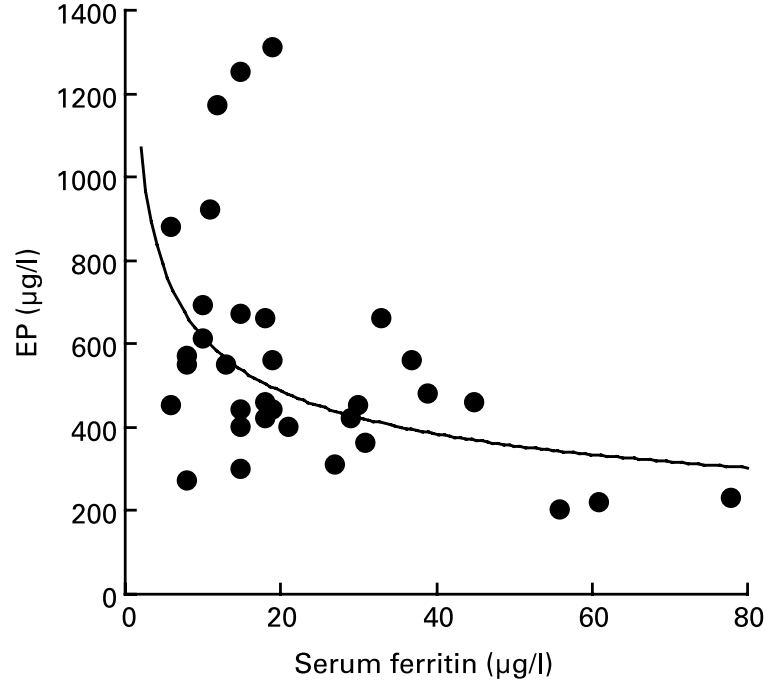

Fig. 2. Relationship between serum ferritin and erythrocyte protoporphyrin $(E P)$. Linear regression between logarithmically transformed serum ferritin and logarithmically transformed EP was calculated. The regression line in the Cartesian coordinate system with the untransformed axes of serum ferritin and $E P$ can be described by: $E P(\mu \mathrm{g} / \mathrm{l})=1354 S F(\mu \mathrm{g} / \mathrm{l})^{-0.341}$, where $S F$ denotes serum ferritin ( $n$ 33; $R^{2} 0.234 ; P<0.005 ; F$ test).

serum ferritin positively correlated with EZP/FFM. For plasma $\mathrm{Zn}$, only serum Fe was significantly associated by stepwise regression analysis.

Because non-linearity was found by inspection of the plot of serum ferritin $v$. $Q_{2}$, the relationship between serum ferritin and $Q_{2}$ was analysed by non-linear regression with the broken-line equation. After serial removal of outliers when the $P$ values for the Studentised residual were $<0.05$ with Bonferroni's correction in each step of non-linear regression, the final values of the coefficients of the broken-line equation were obtained. Fig. 3 indicates the plot of the included subjects, outliers and the regression line. The broken line fitted to the data was described by the following equation:

$$
Q_{2}(\mu \mathrm{mol})=\alpha(S F(\mu \mathrm{g} / \mathrm{l})-\beta)+\alpha|S F(\mu \mathrm{g} / \mathrm{l})-\beta|+\gamma,
$$

where $S F$ denotes serum ferritin, $\alpha$ denotes a half value of the slope of the broken line above the breakpoint, $\beta$ denotes serum

Table 1. Characteristics of women who did not take oral contraceptives and iron or zinc nutritional supplements ( $n$ 33)

(Mean values and standard deviations)

\begin{tabular}{|c|c|c|c|c|c|}
\hline & Mean & SD & Median & Minimum & Maximum \\
\hline Age (years) & $30 \cdot 2$ & $5 \cdot 2$ & $30 \cdot 0$ & $19 \cdot 0$ & $39 \cdot 0$ \\
\hline Body weight (kg) & $64 \cdot 8$ & $14 \cdot 4$ & $60 \cdot 0$ & $45 \cdot 8$ & $108 \cdot 4$ \\
\hline Body height $(\mathrm{m})$ & 1.62 & 0.07 & 1.61 & 1.49 & $1 \cdot 78$ \\
\hline Body mass index $\left(\mathrm{kg} / \mathrm{m}^{2}\right)$ & $24 \cdot 7$ & $5 \cdot 5$ & $22 \cdot 7$ & $18 \cdot 1$ & $38 \cdot 4$ \\
\hline Fat-free mass $(\mathrm{kg})^{*}$ & $45 \cdot 0$ & $6 \cdot 4$ & $43 \cdot 6$ & $34 \cdot 0$ & $65 \cdot 2$ \\
\hline Serum ferritin $(\mu \mathrm{g} / \mathrm{l})$ & $19 \dagger$ & $2 \ddagger$ & 18 & 6 & 78 \\
\hline Serum Fe $(\mu \mathrm{mol} / /)^{*}$ & $11 \cdot 6 \dagger$ & $0.29 \ddagger$ & 11.4 & $5 \cdot 1$ & $32 \cdot 2$ \\
\hline Erythrocyte protoporphrin ( $\mu \mathrm{g} / \mathrm{l})$ & $499 \dagger$ & $16 \ddagger$ & 460 & 200 & 1310 \\
\hline Haemoglobin $(g / l)$ & 131 & 8 & 131 & 114 & 155 \\
\hline Plasma Zn ( $\mu \mathrm{mol} / \mathrm{l})$ & $10 \cdot 7$ & 1.6 & 10.5 & 7.5 & 14.4 \\
\hline
\end{tabular}


Table 2. Food frequencies (times/week) of women who did not take oral contraceptives and iron or zinc nutritional supplements $(n 33)$

(Mean values and standard deviations)

\begin{tabular}{|c|c|c|c|c|c|}
\hline Food item & Mean & SD & Median & Minimum & Maximum \\
\hline Beef & $2 \cdot 1$ & $2 \cdot 0$ & 1 & 0 & 7 \\
\hline Vitamin C-fortified drinks & 0.3 & $1 \cdot 2$ & 0 & 0 & 7 \\
\hline Orange juice & $3 \cdot 8$ & $5 \cdot 2$ & 1 & 0 & 21 \\
\hline Egg dishes & $1 \cdot 7$ & 1.9 & 1 & 0 & 7 \\
\hline Yoghurt & $1 \cdot 2$ & 1.7 & 0.5 & 0 & 7 \\
\hline Milk & $3 \cdot 1$ & $5 \cdot 5$ & 0.5 & 0 & 21 \\
\hline Coffee & $6 \cdot 6$ & $6 \cdot 8$ & 5 & 0 & 21 \\
\hline Tea & $2 \cdot 2$ & 4.4 & 0.5 & 0 & 21 \\
\hline Beans & 1.8 & 1.9 & 1 & 0 & 7 \\
\hline Bran breakfast cereals* & 0.6 & 1.5 & 0 & 0 & 7 \\
\hline
\end{tabular}

Table 3. Associations between zinc pool sizes and plasma zinc concentration, serum iron concentration, and serum ferritin concentration $\dagger$

(Correlation coefficients)

\begin{tabular}{|c|c|c|c|c|c|c|}
\hline & \multicolumn{2}{|c|}{ Plasma Zn (n 32) } & \multicolumn{2}{|c|}{ Serum Fe ( $n$ 31) } & \multicolumn{2}{|c|}{ Serum ferritin ( $n$ 32) } \\
\hline & $r$ & $P$ & $r$ & $P$ & $r$ & $P$ \\
\hline Plasma Zn & - & - & 0.457 & $0.009^{*}$ & 0.449 & $0.009^{*}$ \\
\hline$Q_{1} /$ FFM & 0.383 & $0.030^{*}$ & 0.290 & $0 \cdot 113$ & 0.400 & $0.023^{*}$ \\
\hline$Q_{2}$ & $0.675 \ddagger$ & $0.001^{*}$ & $0.550 \S$ & $0.001^{*}$ & $0.516 \ddagger$ & $0.002^{*}$ \\
\hline$Q_{3} / \mathrm{FFM}$ & 0.204 & 0.263 & 0.203 & 0.273 & 0.409 & $0.020^{*}$ \\
\hline EZP/FFM & 0.307 & 0.087 & 0.267 & 0.147 & 0.453 & $0.009^{*}$ \\
\hline TR/FFM & $0 \cdot 110$ & 0.549 & -0.062 & 0.740 & 0.278 & 0.123 \\
\hline
\end{tabular}

$Q_{1}$, size of the central Zn pool (compartment 1 in Fig. 1); FFM, fat-free mass; $Q_{2}$, size of the lesser peripheral $\mathrm{Zn}$ pool (compartment 2 in Fig. 1); $Q_{3}$, size of the greater peripheral $\mathrm{Zn}$ pool (compartment 3 in Fig. 1); EZP, rapidly exchangeable $Z n$ pool size, a sum of $Q_{1}, Q_{2}$ and $Q_{3}$; TR, plasma $Z n$ turnover rate.

${ }^{*}$ Correlation was significant $(P<0.05)$.

$\dagger P$ values were determined by $F$ test.

$\ddagger n 33$.

$\S n 32$.

ferritin at the breakpoint, and $\gamma$ denotes the value of $Q_{2}$ at the horizontal section of the broken line. The estimate of serum ferritin at the breakpoint ( $\beta$ ) was 21.0 (asymptotic SE 2.9) $\mu \mathrm{g} / \mathrm{l}$. The estimate of $Q_{2}$ at the horizontal section of the broken line $(\gamma)$ was 73.1 (asymptotic SE 4.3) $\mu$ mol. The estimate of the slope above the breakpoint $(2 \alpha)$ was 4.02 (asymptotic SE 0.41) $\mu \mathrm{mol} / \mu \mathrm{g}$ per 1 .

Outliers were serially detected when the $P$ values for the Studentised residual in non-linear regression were $<0.05$ with Bonferroni's correction. By this procedure, five outliers were detected. In subject nos. 104, 114 and 159, $Q_{2}$ was higher than the estimate from serum ferritin concentration. In subject nos. 156 and 312, $Q_{2}$ was lower than the estimate from serum ferritin concentration. No outlier reported bleeding through menstrual pads.

\section{The outliers found were classified into three groups}

Group 1 included subjects 156 and 312 and was characterised by a high frequency of intake of vitamin C-rich foods (Zn absorption inhibitors and $\mathrm{Fe}$ absorption enhancers) consistent with a negative deviation of $Q_{2}$ compared with serum ferritin. Subject no. 156 had a frequency of intake of orange juice of five times/week and a frequency of intake of vitamin C-fortified drinks of 0.5 times/week. Subject no. 312 had a frequency of intake of orange juice of seven times/week and a frequency of intake of vitamin C-fortified drinks of 0.5 times/week.

Group 2 included subjects 104 and 159 and was characterised by a low frequency of intake of vitamin C-rich foods ( $\mathrm{Zn}$ absorption inhibitors and Fe absorption enhancers) consistent with a positive deviation of $Q_{2}$ compared with serum ferritin. Subject no. 104 had a frequency of intake of orange juice of 0.5 times/week and a frequency of intake of vitamin C-fortified drinks of zero. Subject no. 159 had a frequency of intake of orange juice of zero and a frequency of intake of vitamin $\mathrm{C}$-fortified drinks of zero and had a higher frequency of intake of a possible $\mathrm{Zn}$ absorption enhancer (yoghurt seven times/week).

Group 3 included subject 114 and was characterised by a low $\mathrm{Zn}$ loss consistent with a positive deviation of $Q_{2}$ compared with serum ferritin. Subject no. 114 had an extremely low urinary $\mathrm{Zn}$ excretion rate constant (0.0645/d) compared with hypozincaemic subjects (average excretion rate constant, $0 \cdot 175 / \mathrm{d})$ and normozincaemic subjects $(0 \cdot 344 / \mathrm{d})^{6}$.

Because these outliers had conspicuous food frequencies as shown above, we tried to explain the association between $\mathrm{Fe}$ parameters and $\mathrm{Zn}$ pool sizes based on the common factors 
Table 4. Iron parameters affecting zinc pool sizes examined by stepwise multiple regression analysis* (Simple and multiple regression coefficients)

\begin{tabular}{|c|c|c|c|c|}
\hline & \multicolumn{2}{|c|}{ Simple regression } & \multicolumn{2}{|c|}{ Multiple regression } \\
\hline & Regression coefficient & $P$ & Regression coefficient & $P$ \\
\hline \multicolumn{5}{|c|}{$Q_{1} / \mathrm{FFM}(\mu \mathrm{mol} / \mathrm{kg})\left(n 30 ; R^{2} 0.450 ;\right.$ SE of estimate $\left.0.122 ; P<0.001\right)$} \\
\hline Constant & - & - & 0.568 & 0.001 \\
\hline Serum ferritin $(\mu \mathrm{g} / \mathrm{l})$ & 0.00851 & 0.001 & 0.00748 & 0.001 \\
\hline BTMP & -0.147 & 0.056 & -0.105 & 0.095 \\
\hline \multicolumn{5}{|c|}{$Q_{2}(\mu \mathrm{mol})\left(n 30 ; R^{2} 0.569\right.$, SE of estimate $\left.39.3 ; P<0.001\right)$} \\
\hline Constant & - & - & 18.5 & $0 \cdot 249$ \\
\hline Serum ferritin $(\mu \mathrm{g} / \mathrm{l})$ & $2 \cdot 16$ & 0.001 & 1.60 & 0.002 \\
\hline Serum Fe $(\mu \mathrm{mol} / \mathrm{l})$ & 0.916 & 0.001 & 0.588 & 0.009 \\
\hline \multicolumn{5}{|c|}{$Q_{3} / \mathrm{FFM}(\mu \mathrm{mol} / \mathrm{kg})\left(n 31 ; R^{2} 0.377 ;\right.$ SE of estimate $\left.6 \cdot 16 ; P=0.001\right)$} \\
\hline Constant & - & - & 106 & $<0.001$ \\
\hline Body height $(\mathrm{m})$ & $-39 \cdot 9$ & 0.039 & $-41 \cdot 2$ & 0.015 \\
\hline Serum ferritin $(\mu \mathrm{g} / \mathrm{l})$ & 0.256 & 0.006 & 0.261 & 0.003 \\
\hline \multicolumn{5}{|c|}{ EZP/FFM $(\mu \mathrm{mol} / \mathrm{kg})\left(n 32 ; R^{2} 0.309 ;\right.$ SE of estimate $\left.7.19 ; P=0.004\right)$} \\
\hline Constant & - & - & 104 & 0.001 \\
\hline Body height (m) & -37.9 & 0.080 & $-38 \cdot 8$ & 0.046 \\
\hline Serum ferritin $(\mu \mathrm{g} / \mathrm{l})$ & 0.271 & 0.009 & 0.274 & 0.006 \\
\hline \multicolumn{5}{|c|}{$\begin{array}{l}Q_{1} \text {, size of the central Zn pool (compartment } 1 \text { in Fig. 1); FFM, fat-free mass; BTMP, bleeding through menstrual pads (yes or no: } 1 \\
\text { was given for 'yes'; } 0 \text { was given for 'no'); } Q_{2} \text {, size of the lesser peripheral Zn pool (compartment } 2 \text { in Fig. } 1 \text { ); } Q_{3} \text {, size of the greater } \\
\text { peripheral Zn pool (compartment } 3 \text { in Fig. 1); EZP, rapidly exchangeable Zn pool size. }\end{array}$} \\
\hline \multicolumn{5}{|c|}{$\begin{array}{l}\text { The potential variables included in the initial variable set were body height, } \mathrm{Hb} \text {, serum ferritin, serum } \mathrm{Fe} \text { and } \mathrm{BTMP} \text { for } Q_{1} / \mathrm{FFM} \text {, } \\
Q_{3} / \mathrm{FFM} \text { and EZP/FFM. For } Q_{2} \text {, FFM was also included in the potential variables. } P \text { values were determined by } F \text { test. }\end{array}$} \\
\hline
\end{tabular}

including food frequencies, anthropometric parameters and menstrual blood loss.

Association between subjects' food intake histories and serum ferritin and zinc pool sizes

The association of serum ferritin with food frequencies and bleeding through menstrual pads is shown in Table 5. The frequency of beef consumption correlated positively with serum ferritin. Bleeding through menstrual pads correlated negatively with serum ferritin. The negative association between bran breakfast cereal consumption and serum ferritin was marginal. For serum Fe, only the frequency of consumption of coffee was selected by stepwise regression. The constant was 9.6 (SD 1.3) and the regression coefficient was 0.435 (SE 0.138) ( $n$ 31; $R^{2} 0.254$; SE of estimate 5.2; $P=0 \cdot 004)$. The association of plasma $\mathrm{Zn}$ with food frequencies is shown in Table 6 . The frequency of consumption of coffee was found to be a positive predictor while the frequency of consumption of orange juice was a negative predictor for plasma $\mathrm{Zn}$.

The association of $\mathrm{Zn}$ pool sizes with food frequencies and bleeding through menstrual pads is shown in Table 7. Beef was found to be a positive determinant of $Q_{1} / \mathrm{FFM}$. Bleeding through menstrual pads and the frequency of bran breakfast cereals consumption were negative predictors of $Q_{1} / \mathrm{FFM}$. The frequencies of yoghurt, coffee and beef consumption were positive determinants of $Q_{2}$. The frequencies of bran breakfast cereal and orange juice consumptions as well as bleeding through menstrual pads were negatively correlated with $Q_{2}$. The negative association of egg consumption on $Q_{2}$ was marginal. The frequency of beef consumption was positively correlated with $Q_{3} / \mathrm{FFM}$. Presence of bleeding through menstrual pads was a negative predictor of $Q_{3} / \mathrm{FFM}$. The association of body height with $Q_{3} / \mathrm{FFM}$ was marginal. The frequencies of beef consumption and coffee consumption were positively correlated with EZP/FFM. Body height and bleeding through menstrual pads were negatively correlated with EZP/FFM.

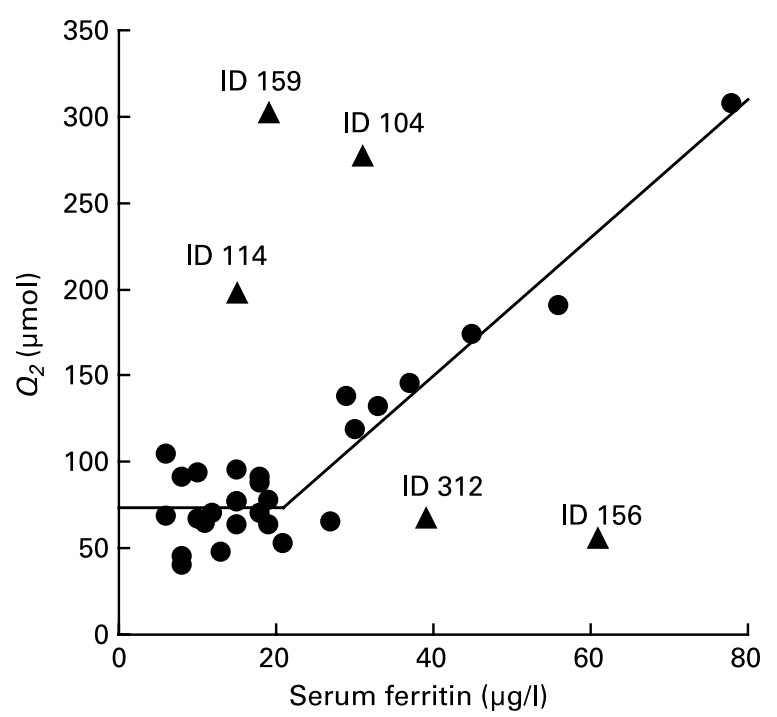

Fig. 3. Non-linear relationship between serum ferritin and the lesser peripheral $\mathrm{Zn}$ pool size $\left(Q_{2}\right)$. The broken line fitted to the data was described by the following equation: $Q_{2}(\mu \mathrm{mol})=2.007 \quad(S F \quad(\mu \mathrm{g} / \mathrm{l})-21.0)+2.007$ $|S F(\mu \mathrm{g} / \mathrm{l})-21.0|+73.1$, where $S F$ denotes serum ferritin $\left(n 28 ; R^{2} 0.891\right.$; $P<0.001 ; F$ test). $(\bullet)$, Data included in the broken-line model; $(\boldsymbol{\Lambda})$, outliers with a subject identification (ID) number. Outliers were classified into three groups. Group 1 includes subject nos. 156 and 312 who had a high frequency of consumption of vitamin C-rich foods ( $\mathrm{Zn}$ absorption inhibitors and $\mathrm{Fe}$ absorption enhancers) consistent with a negative deviation of $Q_{2}$ compared with serum ferritin. Group 2 includes subject nos. 104 and 159 who had a low frequency of intake of vitamin C-rich foods ( $\mathrm{Zn}$ absorption inhibitors and Fe absorption enhancers) consistent with a positive deviation of $Q_{2}$ compared with serum ferritin. Group 3 includes subject no. 114 who had a low urinary $\mathrm{Zn}$ loss consistent with a positive deviation of $Q_{2}$ compared with serum ferritin. 
Table 5. Associations of serum ferritin $(\mu \mathrm{g} / \mathrm{l})$ with food frequencies (times/week) and bleeding through menstrual pads (BTMP) examined by stepwise multiple regression analysis $(n 29)^{*}$

(Regression coefficients and partial correlation coefficients)

\begin{tabular}{lcccr}
\hline Variable & Regression coefficient & SE & Partial correlation coefficient & $P$ \\
\hline Constant & 14.8 & 2.2 & - & $<0.001$ \\
Bran breakfast cereals & -2.14 & 1.05 & -0.376 & 0.053 \\
Beef & 3.48 & 0.82 & 0.645 & $<0.001$ \\
BTMP† & -12.2 & 4.4 & -0.481 & 0.011 \\
\hline
\end{tabular}

The dependent variable entered was serum ferritin $(\mu \mathrm{g} / \mathrm{l})$. The independent variables included in the model explain $44 \%$ of the variation in serum ferritin $\left(R^{2} 0.443\right.$; SE of estimate 8.20; $P=0.002 ; F$ test). The potential variables included in the initial variable set were consumption (times/week) of beef, vitamin C-fortified drinks, orange juice, eggs, yoghurt, milk, coffee, tea, beans and bran breakfast cereals, and body height, fat-free mass and BTMP.

†Yes or no: 1 was given for 'yes'; 0 was given for 'no'.

\section{Discussion}

Association between iron and zinc indices

Consistent with our hypothesis, simple and multiple regression analyses and non-linear regression found strong associations between $\mathrm{Zn}$ (plasma $\mathrm{Zn}$ and $\mathrm{Zn}$ pool sizes) and Fe parameters (serum $\mathrm{Fe}$ and serum ferritin). There were some outliers from the regression line of serum ferritin $v$. $\mathrm{Zn}$ pool size $Q_{2}$. The outliers were explainable based on their extreme characteristics for food frequencies and $\mathrm{Zn}$ kinetics, consistent with the following discussion obtained from the analysis of the relationship between dietary and host factors and indices of $\mathrm{Zn}$ and $\mathrm{Fe}$.

\section{Dietary and host factors that affect iron stores}

The critical role of food choice in Fe nutriture was confirmed again. The positive correlation between frequency of beef consumption and serum ferritin was consistent with previous reports ${ }^{10,15,35-38}$. The frequency of consumption of bran breakfast cereals was inversely but marginally associated with serum ferritin. This is consistent with the fact that phytate and fibres in bran are inhibitors of Fe absorption ${ }^{39,40}$.

The inverse association between menstrual blood loss and $\mathrm{Fe}$ stores was confirmed ${ }^{10,12,41,42}$. A history of 'bleeding through menstrual pads' corresponded to an average $12 \mu \mathrm{g} / \mathrm{l}$ decrease in serum ferritin concentration in the present study. In our previous study ${ }^{10}$, a history of 'bleeding through menstrual pads' corresponded to an average $14 \mu \mathrm{g} / \mathrm{l}$ decrease in serum ferritin concentration. Thus a history of 'bleeding through menstrual pads' can be considered a probable indicator of Fe depletion.

\section{Dietary and host factors that affect zinc pool sizes}

Beef and other red meats are sources of highly bioavailable $\mathrm{Zn}^{5,43,44}$. Therefore it was not surprising that we found a significant positive association between the frequency of beef consumption and $\mathrm{Zn}$ pool sizes, which was consistent with our previous finding of a significant inverse correlation between frequency of red meat consumption and plasma $\mathrm{Zn}$ disappearance ${ }^{10}$.

Bran cereals contain phytate, dietary fibres and products of non-enzymic Maillard browning that inhibit $\mathrm{Zn}$ absorption $^{45-53}$. Therefore we were not surprised to find that the frequency of consumption of bran breakfast cereals correlated inversely with $Q_{1} / \mathrm{FFM}$ and $Q_{2}$.

Coffee also contains $\mathrm{Zn}$-chelating polyphenolic substances, such as a melanoidin-like polymer, that potentially bind $\mathrm{Zn}$ and inhibit its absorption ${ }^{54-57}$. We were surprised to find frequency of coffee consumption directly correlated with $\mathrm{Zn}$ pool sizes. Perhaps this is consistent with the findings that discontinuation of coffee for 5 months did not change plasma $\mathrm{Zn}$ concentrations or haematological status of Fe-deficient Guatemalan toddlers ${ }^{58}$, that coffee fed to rats did not affect tissue $\mathrm{Zn}$ concentration $^{59}$ and that caffeine has no apparent effect on the intestinal absorption of $\mathrm{Zn}^{60}$.

We found that the frequent consumption of orange juice, a rich source of vitamin $\mathrm{C}$, was associated with lower plasma $\mathrm{Zn}$ concentrations and smaller $Q_{2}$. Subjects nos. 156 and 312, whose $Q_{2}$ was lower than the predicted values from their

Table 6. Associations of plasma zinc $(\mu \mathrm{mol} / \mathrm{l})$ with food frequencies (times/week) examined by stepwise multiple regression analysis $(n 31)^{\star}$

(Regression coefficients and partial correlation coefficients)

\begin{tabular}{lcccr}
\hline Variable & Regression coefficient & SE & Partial correlation coefficient & $P$ \\
\hline Constant & 10.3 & 0.3 & - & $<0.001$ \\
Coffee & 0.0927 & 0.0335 & 0.463 & 0.010 \\
Orange juice & -0.0899 & 0.0427 & -0.369 & 0.045
\end{tabular}

* The dependent variable entered was plasma $\mathrm{Zn}$. The independent variables included in the model explain $25 \%$ of the variation in plasma $\mathrm{Zn}\left(R^{2} 0.252 ; \mathrm{SE}\right.$ of estimate 1.2; $P=0.017 ; F$ test). The potential variables included in the initial variable set were consumption (times/week) of beef, vitamin $C$-fortified drinks, orange juice, eggs, yoghurt, milk, coffee, tea, beans and bran breakfast cereals, and body height, fat-free mass and bleeding through menstrual pads. 
Table 7. Associations of zinc pool sizes with food frequencies (times/week) examined by stepwise multiple regression analysis* (Regression coefficients and partial correlation coefficients)

\begin{tabular}{|c|c|c|c|c|}
\hline & Regression coefficient & SE & Partial correlation coefficient & $P$ \\
\hline \multicolumn{5}{|c|}{$Q_{1} / \mathrm{FFM}(\mu \mathrm{mol} / \mathrm{kg})\left(n 30 ; R^{2} 0.317 ;\right.$ SE of estimate $\left.0.132 ; P=0.018\right)$} \\
\hline Constant & 0.680 & 0.036 & - & $<0.001$ \\
\hline Bran breakfast cereals & -0.0406 & $0 \cdot 0169$ & -0.425 & 0.024 \\
\hline Beef & 0.0281 & 0.0132 & 0.387 & 0.042 \\
\hline BTMP & -0.198 & 0.071 & -0.481 & 0.010 \\
\hline \multicolumn{5}{|c|}{$Q_{2}(\mu \mathrm{mol})\left(n 30 ; R^{2} 0.595 ;\right.$ SE of estimate $\left.46.4 ; P=0.002\right)$} \\
\hline Constant & $82 \cdot 2$ & $17 \cdot 6$ & - & $<0.001$ \\
\hline Bran breakfast cereals & $-22 \cdot 8$ & $6 \cdot 3$ & -0.611 & 0.002 \\
\hline Yoghurt & $16 \cdot 1$ & $5 \cdot 6$ & 0.525 & 0.008 \\
\hline Coffee & 4.03 & 1.46 & 0.507 & 0.011 \\
\hline Beef & $12 \cdot 6$ & $5 \cdot 1$ & 0.467 & 0.021 \\
\hline Orange juice & $-4 \cdot 28$ & $1 \cdot 80$ & -0.451 & 0.027 \\
\hline Eggs & -8.26 & $4 \cdot 72$ & -0.350 & 0.094 \\
\hline BTMP & $-56 \cdot 2$ & $26 \cdot 2$ & -0.415 & 0.044 \\
\hline \multicolumn{5}{|c|}{$Q_{3} / \mathrm{FFM}(\mu \mathrm{mol} / \mathrm{kg})\left(n 31 ; R^{2} 0.381 ;\right.$ SE of estimate $\left.6.64 ; P=0.004\right)$} \\
\hline Constant & 98.9 & $29 \cdot 7$ & - & 0.003 \\
\hline Body height (m) & $-35 \cdot 3$ & $18 \cdot 2$ & -0.356 & 0.063 \\
\hline Beef & 1.85 & 0.65 & 0.488 & 0.008 \\
\hline BTMP & -8.96 & 3.47 & -0.451 & 0.016 \\
\hline \multicolumn{5}{|c|}{ EZP/FFM $(\mu \mathrm{mol} / \mathrm{kg})\left(n 31 ; \mathrm{R}^{2} 0.489 ;\right.$ SE of estimate $\left.6.51 ; P=0.001\right)$} \\
\hline Constant & 99.2 & $29 \cdot 2$ & - & 0.002 \\
\hline Body height $(\mathrm{m})$ & -34.9 & $17 \cdot 8$ & -0.358 & 0.001 \\
\hline Coffee & 0.377 & 0.181 & 0.377 & 0.048 \\
\hline Beef & 1.83 & 0.64 & 0.489 & 0.008 \\
\hline BTMP & -11.5 & 3.5 & -0.547 & 0.003 \\
\hline
\end{tabular}

$Q_{1}$, size of the central Zn pool (compartment 1 in Fig. 1); FFM, fat-free mass; BTMP, bleeding through menstrual pads (yes or no: 1 was given for 'yes'; 0 was given for ' $n o$ '); $Q_{2}$, size of the lesser peripheral $Z n$ pool (compartment 2 in Fig. 1); $Q_{3}$, size of the greater peripheral Zn pool (compartment 3 in Fig. 1); EZP, rapidly exchangeable Zn pool size.

* The potential variables included in the initial variable set were consumption (times/week) of beef, vitamin C-fortified drinks, orange juice, eggs, yoghurt, milk, coffee, tea, beans and bran breakfast cereals, body height, and BTMP for $Q_{1} / F F M, Q_{3} / F F M$ and EZP/FFM. For $Q_{2}$, FFM was also included in the potential variables. $P$ values were determined by $F$ test.

serum ferritin concentrations by the broken-line regression (Fig. 3), reported a higher frequency of consumption of vitamin C-rich foods. In contrast, subjects nos. 159 and 104 reported a lower frequency of consumption of vitamin C-rich foods and had higher $Q_{2}$ than expected from serum ferritin (Fig. 3). These findings are consistent with the findings of Kies et al. ${ }^{61}$ from balance studies of lower $\mathrm{Zn}$ retention in subjects supplemented with vitamin C. On the other hand Solomon et al. ${ }^{62}$ and Sandström \& Cederblad ${ }^{63}$ did not find that vitamin $\mathrm{C}$ decreased $\mathrm{Zn}$ absorption. The higher frequency of yoghurt consumption was associated with larger $Q_{2}$. Subject no. 159, whose $Q_{2}$ was higher than the predicted value from her serum ferritin concentration by the brokenline regression (Fig. 3), reported extremely high frequency of consumption of yoghurt (seven times/week). Lactic acid in the yoghurt increased $\mathrm{Zn}$ solubility and thus enhanced intestinal $\mathrm{Zn}$ absorption.

Stepwise multiple regression analysis using food frequencies and menstrual bleeding selected excessive menstrual blood loss as a negative predictor of $\mathrm{Zn}$ pool sizes. This finding suggests that the loss of $\mathrm{Zn}$ in erythrocytes was sufficient to impair Zn nutriture.

\section{Proposal for a screening test to detect low zinc status}

Performance of plasma $\mathrm{Zn}$ and serum ferritin as a screening test for small $\mathrm{Zn}$ pool size can be evaluated when a $Q_{2}$ of $112 \mu \mathrm{mol}(7.3 \mathrm{mg})$ is set as the critical value of a small $\mathrm{Zn}$ pool size ${ }^{6}$. We found low $Q_{2}(<112 \mu \mathrm{mol})$ present in twenty of twenty-three subjects with plasma $\mathrm{Zn}$ $<11.5 \mu \mathrm{mol} / 1 \mathrm{l}(750 \mu \mathrm{g} / \mathrm{l})$ and in three of ten subjects with plasma $\mathrm{Zn} \geq 11.5 \mu \mathrm{mol} / \mathrm{l}$ (OR 15.6; $P=0.002$; Fisher's exact probability test). The sensitivity was $74.1 \%$ and specificity was $50.0 \%$. Low $Q_{2}(<112 \mu \mathrm{mol}$ or $7.3 \mathrm{mg})$ was evident in nineteen of twenty-one subjects with serum ferritin $<20 \mu \mathrm{g} / \mathrm{l}$ and in four of twelve subjects with serum ferritin $\geq 20 \mu \mathrm{g} / 1$ (OR 19.0; $P=0.001$; Fisher's exact probability test). The sensitivity was $70.4 \%$ and specificity was $66.7 \%$. When co-occurrence of low plasma $\mathrm{Zn}(<11.5 \mu \mathrm{mol} / \mathrm{l})$ and low serum ferritin $(<20 \mu \mathrm{g} / \mathrm{l})$ was used as a criterion for detecting low $Q_{2}(<112 \mu \mathrm{mol}$ or $7.3 \mathrm{mg})$, low $Q_{2}$ was present in sixteen of seventeen subjects with both low plasma $\mathrm{Zn}$ and low serum ferritin, and in seven of sixteen subjects with normal plasma $\mathrm{Zn}$ or normal serum ferritin (OR 20.6; $P=0.002$ ). The sensitivity was $64.0 \%$ and specificity was $87.5 \%$. The combination of plasma $\mathrm{Zn}$ and serum ferritin improved specificity while sensitivity was slightly decreased. We propose that serum ferritin or the combination of serum ferritin and plasma $\mathrm{Zn}$ might be useful as a screening test for low $\mathrm{Zn}$ nutriture, and a basis for confirmatory studies.

In conclusion, we found high associations between indices of $\mathrm{Zn}$ nutriture (plasma $\mathrm{Zn}$ and $\mathrm{Zn}$ pool sizes) and Fe nutriture (serum $\mathrm{Fe}$ and serum ferritin) in premenopausal women with normal $\mathrm{Fe}$ status or low $\mathrm{Fe}$ status without anaemia. Both low Fe stores and low $\mathrm{Zn}$ pool sizes were likely to be derived from common dietary and host factors. For both $\mathrm{Zn}$ pool sizes and serum ferritin, beef was a positive predictor, and bran breakfast cereals and bleeding through menstrual pads were 
negative predictors. Premenopausal women who (a) infrequently consume sources of bioavailable $\mathrm{Zn}$ and $\mathrm{Fe}$, or (b) infrequently consume rich sources of enhancers of $\mathrm{Zn}$ and $\mathrm{Fe}$ absorption and (c) frequently consume rich sources of inhibitors of $\mathrm{Zn}$ and $\mathrm{Fe}$ absorption and/or (d) have excessive menstrual bleeding are likely to be at risk of simultaneous deficiencies of $\mathrm{Zn}$ and $\mathrm{Fe}$.

\section{Acknowledgements}

The present study was supported in part by US Department of Defense Army grant DAMD 17-95-C-5112, and grant M01 RR 00073 from the National Center for Research Resources, National Institutes of Health, United States Public Health Service, that funded the General Clinical Research Center at the University of Texas Medical Branch at Galveston.

\section{References}

1. Prasad AS, Halsted JA \& Nadimi M (1961) Syndrome of iron deficiency anemia, hepatosplenomegaly, hypogonadism, dwarfism, and geophagia. Am J Med 31, 532-546.

2. Prasad A, Miale A, Farid Z, Sandstead HH \& Schulert A (1963) Zinc metabolism in patients with syndrome of iron deficiency anemia, hepato-splenomegaly, dwarfism and hypogonadism. J Lab Clin Med 61, 537-549.

3. Prasad AS, Miale A Jr, Farid Z, Sandstead HH, Schulert AR \& Darby WJ (1963) Biochemical studies on dwarfism, hypogonadism, and anemia. Arch Intern Med 111, 407-428.

4. Sandstead HH (1991) Zinc deficiency: a public health problem. Am J Dis Child 145, 835-859.

5. Sandstead HH (2000) Causes of iron and zinc deficiencies and their effects on brain. $J$ Nutr 130, 347S-349S.

6. Yokoi K, Egger NG, Ramanujam VM, Alcock NW, Dayal HH, Penland JG \& Sandstead HH (2003) Association between plasma zinc concentration and zinc kinetic parameters in premenopausal women. Am J Physiol Endocrinol Metab 285, E1010-E1020.

7. Wasantwisut E, Winichagoon $\mathrm{P}$, Chitchumroonchokchai $\mathrm{C}$, Yamborisut U, Boonpraderm A, Pongcharoen T, Sranacharoenpong K \& Russameesopaphorn W (2006) Iron and zinc supplementation improved iron and zinc status, but not physical growth, of apparently healthy, breast-fed infants in rural communities of northeast Thailand. J Nutr 136, 2405-2411.

8. Pathak P, Kapil U, Kapoor SK, Saxena R, Kumar A, Gupta N, Dwivedi SN, Singh R \& Singh P (2004) Prevalence of multiple micronutrient deficiencies amongst pregnant women in a rural area of Haryana. Indian J Pediatr 71, 1007-1014.

9. Hettiarachchi M, Liyanage C, Wickremasinghe R, Hilmers DC \& Abrahams SA (2006) Prevalence and severity of micronutrient deficiency: a cross-sectional study among adolescents in Sri Lanka. Asia Pac J Clin Nutr 15, 56-63.

10. Yokoi K, Alcock NW \& Sandstead HH (1994) Iron and zinc nutriture of premenopausal women: associations of diet with serum ferritin and plasma zinc disappearance and of serum ferritin with plasma zinc and plasma zinc disappearance. $J$ Lab Clin Med 124, 852-861.

11. Thoradeniya $\mathrm{T}$, Wickremasinghe $\mathrm{R}$, Ramanayake $\mathrm{R}$ \& Atukorala S (2006) Low folic acid status and its association with anaemia in urban adolescent girls and women of childbearing age in Sri Lanka. Br J Nutr 95, 511-516.

12. Fogelholm M, Alopaeus K, Silvennoinen T \& Teirila J (1993) Factors affecting iron status in non-pregnant women from urban South Finland. Eur J Clin Nutr 47, 567-574.
13. Pate RR, Miller BJ, Davis JM, Slentz CA \& Klingshirn LA (1993) Iron status of female runners. Int J Sport Nutr 3, 222-231.

14. Gibson RS, Heath AL \& Ferguson EL (2002) Risk of suboptimal iron and zinc nutriture among adolescent girls in Australia and New Zealand: causes, consequences, and solutions. Asia Pac J Clin Nutr 11, Suppl. 3, S543-S552.

15. Worthington-Roberts B, Breskin M \& Monsen E (1988) Iron status of premenopausal women in a university community and its relationship to habitual dietary sources of protein. Am J Clin Nutr 47, 275-279.

16. Heath AL \& Fairweather-Tait SJ (2002) Clinical implications of changes in the modern diet: iron intake, absorption and status. Best Pract Res Clin Haematol 15, 225-241.

17. Hallberg L \& Rossander-Hultén L (1991) Iron requirements in menstruating women. Am J Clin Nutr 54, 1047-1058.

18. Centers for Disease Control and Prevention (2002) Iron deficiency - United States, 1999-2000. MMWR Morb Mortal Wkly Rep 51, 897-899.

19. Stoltzfus RJ (2001) Iron-deficiency anemia: reexamining the nature and magnitude of the public health problem. Summary: implications for research and programs. $J$ Nutr 131, 697S-701S.

20. Wuehler SE, Peerson JM \& Brown KH (2005) Use of national food balance data to estimate the adequacy of zinc in national food supplies: methodology and regional estimates. Public Health Nutr 8, 812-819.

21. Fairweather-Tait S, Jackson M, Fox T, Wharf S, Eagles J \& Croghan P (1993) The measurement of exchangeable pools of zinc using the stable isotope ${ }^{70} \mathrm{Zn}$. Br J Nutr 70, 221-234.

22. Miller LV, Hambidge KM, Naake VL, Hong Z, Westcott JL \& Fennessey PV (1994) Size of the zinc pools that exchange rapidly with plasma zinc in humans: alternative techniques for measuring and relation to dietary zinc intake. J Nutr $\mathbf{1 2 4}$, 268-276.

23. Jacob RA, Sandstead HH, Klevay LM \& Johnson LK (1980) Utility of serum ferritin as a measure of iron deficiency in normal males undergoing repetitive phlebotomy. Blood 56, 786-791.

24. Cook JD, Lipschitz DA, Miles LE \& Finch CA (1974) Serum ferritin as a measure of iron stores in normal subjects. Am $J$ Clin Nutr 27, 681-687.

25. Penland J, Egger N, Ramanujam V, Dayal H \& Sandstead H (2002) Zinc ( $\mathrm{Zn})$ and iron $(\mathrm{Fe})$ repletion improves cognitive function of mildly deficient women. FASEB $J$ 16, A974.

26. Sandstead HH, Penland JG, Alcock NW, Dayal HH, Chen XC, Li JS, Zhao F \& Yang JJ (1998) Effects of repletion with zinc and other micronutrients on neuropsychologic performance and growth of Chinese children. Am J Clin Nutr 68, 470S-475S.

27. Ronaghy HA, Reinhold JG, Mahloudji M, Ghavami P, Fox MR \& Halsted JA (1974) Zinc supplementation of malnourished schoolboys in Iran: increased growth and other effects. Am J Clin Nutr 27, 112-121.

28. Solomons NW, Ruz M \& Gibson RS (1999) Single-nutrient interventions with zinc. Am J Clin Nutr 70, 111-113.

29. Yokoi K, Alcock NW \& Sandstead HH (1994) Determination of the plasma zinc disappearance constant using stable zinc isotope and inductively coupled plasma-mass spectrometry, and its application for assessing zinc status. Biomed Res Trace Elements 5, 69-76.

30. Kyle UG, Bosaeus I, De Lorenzo AD, et al. (2004) Bioelectrical impedance analysis - part I: review of principles and methods. Clin Nutr 23, 1226-1243.

31. Alcock NW (1987) A hydrogen-peroxide digestion system for tissue trace metal analysis. Biol Trace Elem Res 13, 363-370.

32. Ramanujam VMS, Yokoi K, Egger NG, Dayal HH, Alcock NW \& Sandstead HH (1999) Simplified pretreatment method for the 
analysis of plasma samples applicable to zinc kinetics and inductively coupled plasma-mass spectrometry. Biol Trace Elem Res 68, 143-158.

33. Willett WC, Sampson L, Stampfer MJ, Rosner B, Bain C, Witschi J, Hennekens CH \& Speizer FE (1985) Reproducibility and validity of a semiquantitative food frequency questionnaire. Am J Epidemiol 122, 51-65.

34. Beard JL \& Dawson HD (1997) Iron. In Handbook of Nutritionally Essential Mineral Elements, pp. 275-334 [BL O'Dell and RA Sunde, editors]. New York, USA: Marcel Dekker, Inc.

35. Hallberg L (1981) Bioavailability of dietary iron in man. In Annual Review of Nutrition, pp. 123-147 [W Darby, H Broquist and R Olson, editors]. Palo Alto, CA: Annual Reviews Inc

36. Soustre Y, Dop MC, Galan P \& Hercberg S (1986) Dietary determinants of the iron status in menstruating women. Int $J$ Vitam Nutr Res 56, 281-286.

37. Fleming DJ, Jacques PF, Dallal GE, Tucker KL, Wilson PW \& Wood RJ (1998) Dietary determinants of iron stores in a freeliving elderly population: The Framingham heart study. Am J Clin Nutr 67, 722-733.

38. Ortega RM, Lopez-Sobaler AM, Requejo AM, Quintas ME, Gaspar MJ, Andres P \& Navia B (1998) The influence of meat consumption on dietary data, iron status and serum lipid parameters in young women. Int J Vitam Nutr Res $\mathbf{6 8}$, 255-262.

39. McCance R, Edgecombe C \& Widdowson E (1943) Phytic acid and iron absorption. Lancet ii, 126-128.

40. Brune M, Rossander-Hultén L, Hallberg L, Gleerup A \& Sandberg AS (1992) Iron absorption from bread in humans: inhibiting effects of cereal fiber, phytate and inositol phosphates with different numbers of phosphate groups. J Nutr 122, 442-449.

41. Milman N, Rosdahl N, Lyhne N, Jorgensen T \& Graudal N (1993) Iron status in Danish women aged 35-65 years. Relation to menstruation and method of contraception. Acta Obstet Gynecol Scand 72, 601-605.

42. Kepczyk T, Cremins JE, Long BD, Bachinski MB, Smith LR \& McNally PR (1999) A prospective, multidisciplinary evaluation of premenopausal women with iron-deficiency anemia. Am J Gastroenterol 94, 109-115.

43. O'Dell BL, Burpo CE \& Savage JE (1972) Evaluation of zinc availability in foodstuffs of plant and animal origin. $J$ Nutr 102, 653-660.

44. Gallaher D, Johnson P, Hunt J, Lykken G \& Marchello M (1988) Bioavailability in humans in zinc from beef: intrinsic vs extrinsic labels. Am J Clin Nutr 48, 350-354.

45. Wisker E, Nagel R, Tanudjaja TK \& Feldheim W (1991) Calcium, magnesium, zinc, and iron balances in young women: effects of a low-phytate barley-fiber concentrate. Am J Clin Nutr 54, 553-559.

46. Sandström B \& Sandberg A (1992) Inhibitory effects of isolated inositol phosphates on zinc absorption. $J$ Trace Elem Electrolytes Health Dis 6, 99-103.

47. Knudsen E, Sandström B \& Solgaard P (1996) Zinc, copper and magnesium absorption from a fibre-rich diet. J Trace Elem Med Biol 10, 68-76.

48. Lykken GI, Mahalko J, Johnson PE, Milne D, Sandstead HH, Garcia WJ, Dintzis FR \& Inglett GE (1986) Effect of browned and unbrowned corn products intrinsically labeled with ${ }^{65} \mathrm{Zn}$ on absorption of ${ }^{65} \mathrm{Zn}$ in humans. $J$ Nutr 116, 795-801.

49. Ferguson EL, Gibson RS, Thompson LU \& Ounpuu S (1989) Dietary calcium, phytate, and zinc intakes and the calcium, phytate, and zinc molar ratios of the diets of a selected group of east African children. Am J Clin Nutr 50, 1450-1456.

50. Gibson RS, Smit Vanderkooy PD \& Thompson L (1991) Dietary phytate $\mathrm{x}$ calcium/zinc millimolar ratios and zinc nutriture in some Ontario preschool children. Biol Trace Elem Res 30, 87-94.

51. Ferguson EL, Gibson RS, Opare-Obisaw C, Ounpuu S, Thompson LU \& Lehrfeld J (1993) The zinc nutriture of preschool children living in two African countries. J Nutr 123, 1487-1496.

52. Fitzgerald SL, Gibson RS, Quan de Serrano J, Portocarrero L, Vasquez A, de Zepeda E, Lopez-Palacios CY, Thompson LU, Stephen AM \& Solomons NW (1993) Trace element intakes and dietary phytate/Zn and $\mathrm{Ca} x$ phytate/Zn millimolar ratios of periurban Guatemalan women during the third trimester of pregnancy. Am J Clin Nutr 57, 195-201.

53. Sandström B, Almgren A, Kivisto B \& Cederblad A (1989) Effect of protein level and protein source on zinc absorption in humans. J Nutr 119, 48-53.

54. Pécoud A, Donzel P \& Schelling JL (1975) Effect of foodstuffs on the absorption of zinc sulfate. Clin Pharmacol Ther 17, 469-474.

55. Van Dyck K, Tas S, Robberecht H \& Deelstra H (1996) The influence of different food components on the in vitro availability of iron, zinc and calcium from a composed meal. Int $J$ Food Sci Nutr 47, 499-506.

56. Takenaka M, Sato N, Asakawa H, Wen X, Murata M \& Homma $S$ (2005) Characterization of a metal-chelating substance in coffee. Biosci Biotechnol Biochem 69, 26-30.

57. Wen X, Enokizo A, Hattori H, Kobayashi S, Murata M \& Homma S (2005) Effect of roasting on properties of the zincchelating substance in coffee brews. J Agric Food Chem 53, 2684-2689.

58. Dewey KG, Romero-Abal ME, Quan de Serrano J, Bulux J, Peerson JM, Eagle P \& Solomons NW (1997) Effects of discontinuing coffee intake on iron status of iron-deficient Guatemalan toddlers: a randomized intervention study. Am J Clin Nutr 66, $168-176$.

59. Aldrian PS, Keen CL, Lonnerdal B \& Dewey KG (1997) Effects of coffee consumption on iron, zinc and copper status in nonpregnant and pregnant Sprague-Dawley rats. Int J Food Sci Nutr 48, 177-189.

60. Rossowska MJ \& Nakamoto T (1990) Effect of caffeine on zinc absorption and $\mathrm{Zn}$ concentration in rat tissue. Br J Nutr 64, $553-559$.

61. Kies C, Young E \& McEndree L (1983) Zinc bioavailability from vegetarian diets. Influence of dietary fiber, ascorbic acid, and past dietary practices. In Nutritional Bioavailability of Zinc. ACS Symposium Series, pp. 115-126 [G Inglett, editor]. Washington, DC: American Chemical Society vol. 210,.

62. Solomons NW, Jacob RA, Pineda O \& Viteri FE (1979) Studies on the bioavailability of zinc in man. III. Effects of ascorbic acid on zinc absorption. Am J Clin Nutr 32, 2495-2499.

63. Sandström B \& Cederblad A (1987) Effect of ascorbic acid on the absorption of zinc and calcium in man. Int J Vitam Nutr Res 57, 87-90. 